Vegetalika. 2019. 8(3): 202-219

\title{
Evaluasi Berbagai Genotipe Jagung (Zea mays L.) pada Dua Macam Pemberian Nitrogen
}

\section{Evaluation of Various Corn (Zea mays L.) Genotype with Two Types of Nitrogen Input}

\author{
Reynaldo Christian, Erlina Ambarwati ${ }^{*}$ \\ Departemen Budidaya Pertanian, Fakultas Pertanian, Universitas Gadjah Mada \\ *) Penulis untuk korespondensi Email: erlina.a@ugm.ac.id.
}

\begin{abstract}
Corn (Zea mays L.) has become one of the most important crop with grain yield as the main purpose of cultivation. Most of the economical plant characters, like grain yield, associated by polygenic genes and traits, therefore show massive changes throughout environments. Those fluctuations of genotype performance caused by environmental effects known as Genotype and Environment Interactions (GEI). It caused decreased of association degree between genotype and phenotype, which lead to estimation bias. The purpose of the experiment is to evaluate performance of each cultivar in various nitrogen inputs practice. Experiment occur in May 2017 until September 2017 and held in two type of field in Bantul, Yogyakarta, which is sandy coastal field in Sradakan and ordinary field in Sewon. Each fields divided into two type of fertilizing applications, with and without application of $N$. Material for this experiment are three hybrids cultivars of field corn ('Pioneer-35', 'Bisi 816', 'Bima 20'), three open pollinated cultivars ('Srikandi', 'Sukmaraga', dan 'Lamuru') and one local inbred cultivar, Jagung putih. Hybrids cultivars show higher yield in nitrogen fertilized area and in general. OP cultivars show average yield in every type of nitrogen, while local inbred cultivar shows overall poor performance.
\end{abstract}

Keywords: Zea mays L.; GEl; nitrogen.

\section{INTISARI}

Jagung (Zea mays L.) merupakan salah satu tanaman penting dengan tujuan utama dari budidaya untuk menghasilkan bulir hasil panen. Bulir hasil panen merupakan salah satu sifat kompleks yang dikendalikan oleh berbagai sifat morfologis dan fisiologis. Karakter pada tanaman yang memiliki nilai ekonomis biasanya dipengaruhi oleh karakter poligenik yang kompleks, dan menunjukan pengaruh yang tinggi dari lingkungan. Fluktuasi hasil panen dikenal sebagai efek interaksi genotipe dengan lingkungan (GEI). GEI mengurangi asosiasi antar nilai fenotipik dan genotipik dan menyebabkan bias pada estimasi efek gen. Penelitian dilakukan dengan tujuan mengevaluasi performa berbagai jenis kultivar pada lingkungan dengan bermacam pemberian N. Penelitian ini dilaksanakan di dua macam lahan di daerah Bantul, Yogyakarta dengan karakter lahan berpasir di Srandakan dan lahan sawah di Sewon dengan dua macam pemberian pupuk $\mathrm{N}$ (dengan pupuk $\mathrm{N}$ dan tanpa pupuk $\mathrm{N}$ ). Penelitian dilaksanakan pada akhir bulan Mei 2017 hingga pertengahan bulan September 2017. Dipilih tiga kultivar jagung hibrida komersil ('Pioneer-35', 'Bisi 816', 'Bima 20'), tiga kultivar komposit ('Srikandi', 'Sukmaraga', dan 'Lamuru') dan satu kultivar komposit jagung lokal 
(jagung putih). Hasil menunjukkan kultivar hibrida memiliki performa yang baik pada lingkungan dengan pemberian $\mathrm{N}$. Kultivar OP memiliki performa sedang pada seluruh lingkungan dan kultivar inbrida memiliki performa rendah di seluruh lingkungan.

Kata kunci: Zea mays L.; GEl; stabilitas; AMMI.

\section{PENDAHULUAN}

Jagung (Zea mays L.) memiliki posisi penting dalam tanaman pangan menyebabkan program pemuliaan utama tanaman jagung adalah merakit galur - galur inbrida, kultivar OP (Open Pollinated) maupun hibrida yang saling menyaingi kualitas satu sama lain dalam sebagian besar karakternya (Zarei et al., 2012). Jagung merupakan salah satu tanaman penting dengan tujuan utama dari budidaya untuk menghasilkan bulir hasil panen. Bulir hasil panen merupakan salah satu sifat kompleks yang dikendalikan oleh berbagai sifat morfologis dan fisiologis (Ghalejoughi et al., 2013).

Nitrogen $(\mathrm{N})$, merupakan senyawa penting dalam pembentukan hasil panen tanaman. $\mathrm{N}$ merupakan mineral yang dibutuhkan tanaman dalam jumlah yang banyak, sehingga menjadi faktor nutrisi pembatas yang penting dalam program peningkatan genetik tanaman. Terdapat sekitar 67\% nitrogen yang diserap tanaman akan sampai di bulir pada saat tanaman dewasa. (Belfield dan Brown, 2008). Rao et al. (2016) menyatakan adaptasi tanaman terhadap tanah dengan tingkat kesuburan rendah memiliki sistem pewarisan yang rumit dan dipengaruhi oleh lingkungan tumbuh.

Karakter pada tanaman yang memiliki nilai ekonomis biasanya dipengaruhi oleh karakter poligenik yang kompleks, dan menunjukkan pengaruh yang tinggi dari lingkungan. Alasan tersebut menyebabkan penelitian terhadap karakter tersebut memerlukan beberapa jenis lingkungan untuk mengavaluasinya (Kandus et al., 2010).

GEI mengurangi asosiasi antar nilai fenotipik dan genotipik dan menyebabkan bias pada estimasi efek gen dan daya gabung pada berbebagai karakter yang sensitif terhadap fluktuasi keadaan lingkungan, sehingga seleksi tidak dianggap akurat (Bose et al., 2014).

Kultivar hibrida dibentuk dari persilangan dua galur inbrida yang sudah sangat seragam, hasilnya adalah tanaman dengan vigor yang tinggi dan tanaman yang lebih seragam (Brewbaker, 2003). OP merupakan kultivar yang benihnya dihasilkan oleh berbagai penyerbukan silang yang acak, yang artinya tanaman tidak akan sepenuhnya 
seragam. Performa galur inbrida terbilang buruk, yang diakibatkan sedikitnya alel yang bersifat heterozigot, peristiwa tersebut disebut dengan depresi inbrida (McPhearson, 2011).

Peningkatan kualitas managemen dalam sistem produksi pertanian merupakan hal yang mendasar dalam mengoptimasi hasil tanaman, meminimalisis kehilangan $\mathrm{N}$ dan meningkatkan efisiensi penyerepan nitrogen. (Cambourism et al., 2016). Penelitian dilakukan dengan tujuan melakukan evaluasi pada genotipe-genotipe tanaman jagung pada pemberian $\mathrm{N}$ yang berbeda. Data yang didapatkan digunakan untuk mengkarakterisasi respon masing-masing genotipe pada kondisi nutrisi yang berbeda.

\section{BAHAN DAN METODE PENELITIAN}

Penelitian ini dilaksanakan di dua macam lahan di daerah Bantul, Yogyakarta dengan karakter lahan berpasir di Srandakan dan lahan sawah di Sewon, dan di Laboratorium Teknologi Benih, Laboratorium Genetika dan Pemuliaan Tanaman, dan Laboratorium IImu Tanah untuk kegiatan pengamatan. Penelitian dilaksanakan pada akhir bulan Mei 2017 hingga pertengahan bulan September 2017.

Bahan yang dibutuhkan dalam penelitian ini adalah varietas tanaman jagung yang terdiri dari tiga kultivar jagung hibrida ('Pioneer 35', 'Bisi 816', 'Bima 20'), tiga kultivar OP ('Srikandi', 'Sukmaraga', dan 'Lamuru') dan satu kultivar inbrida (jagung putih), pupuk anorganik (NPK), pupuk limbah kotoran kambing, pestisida, fungisida, herbisida dan kantung jaring.

Penelitian ini menggunakan rancangan acak kelompok lengkap (RAKL) dengan factorial $7 \times 4$, dengan 4 blok sebagai ulangan. Faktor pertama merupakan 7 kultivar jagung. Faktor kedua merupakan 4 jenis lingkungan yaitu lahan tanah pesisir dengan $\mathrm{N}$, lahan tanah pasiran tanpa $\mathrm{N}$, lahan tanah sawah dengan $\mathrm{N}$. lahan tanah sawah tanpa N. Pemberian diberikan dengan dosis $600 \mathrm{~kg} / \mathrm{ha}$ pupuk NPK.

Pengamatan suhu dan kelembapan udara dilakukan dilapangan pada titik insolasi tertinggi yaitu pada rentang pukul 12.00-15.00. Pengamtan dilakukan dari awal penanaman (15 Juli 2017) hingga masa pengeringan tongkol (25 Agustus 2017). Karakter tanah yang diamati merupakan karakteristik tanah, kandungan hara tanah makro dan analisis struktur tanah. Analisis kandungan hara makro meliputi unsur N, P tersedia, dan $\mathrm{K}$, sedangkan analisis tekstur tanah dilakukaan untuk mengetahui persentasi fraksi penyusun tanah. 
Pengamatan hasil dilakukan pada karakter-karakter tinggi tanaman dan tongkol, diameter batang, panjang tongkol, diameter tongkol, banyak bulir per baris, banyak baris per tongkol, jumlah bulir total per tongkol, berat panen total, berat tongkol 10 tongkol, berat pipilan total, berat 100 biji. Variabel estimasi yang ditera adalah nisbah tinggi dan letak tongkol jagung, rendemen, potensi hasil (ton/ha), dengan rumus konversi:

$$
\text { Potensi Hasil }(\text { ton } / \text { ha })=\frac{\text { Berat Panen }}{\text { Jumlah Tongkol } \times 1000} \times \text { Rendemen }(\%) \times J P S
$$

Jumlah populasi standar (JPS) tanaman dengan jarak tanam $40 \times 20 \mathrm{~cm}$ untuk 1 ha adalah 125000 tanaman (Lauer, 2002).

Analisis dilakukan dengan bantuan perangkat lunak $\mathrm{R}$ dengan rancangan RCBD Faktorial 7x4. Seluruh karakter akan diuji dengan ANOVA untuk mengetahui adanya pengaruh nyata dari varietas dan lingkungan. Model matematis sebagai berikut:

$$
Y_{i j k l}=\mu+A_{i}+B_{j}+\rho_{k(j)}+(A B)_{i j}+\delta_{i j k}
$$

$\mu=$ Rerata

$A_{i}=$ Efek pengaruh varietas ke- $i$

$B_{j}=$ Efek pengaruh lingkungan ke- $j$

$\rho_{k}(j)=$ Efek pengaruh blok ke $k$ dalam lingkungan ke $-j$

$(A B)_{i j}=$ Efek varietas ke- $i$ dan variasi lingkungan ke- $j$

$\delta_{i j k}=$ Sesatan.

Karakter yang menunjukan signifikansi akan diuji lanjut dengan Tukey's Honest Significant Difference pada taraf 5\% menggunakan perangkat lunak R.

\section{HASIL DAN PEMBAHASAN}

Kondisi lahan dibagi menjadi dua yaitu lahan pesisir dan sawah. Lahan Srandakan memiliki karakteristik suhu dan penyinaran matahari yang tinggi, tidak memiliki naungan dan kecepatan angin yang tinggi. Lahan Sewon merupakan lahan sawah didekat pemukiman warga dengan suhu dan intensitas cahaya yang tinggi, sebagian kecil lahan ternaungi dan kecepatan angin yang rendah. Hasil pengamatan menunjukan tidak adanya perbedaan dalam intensitas cahaya dan suhu, tetapi kelembapan udara menunjukan Sewon memiliki 
kelembapan udara yang lebih rendah dibanding dengan Srandakan. Regresi kelembapan dan suhu (Gambar 1.) menggambarkan hubungan kedua parameter.

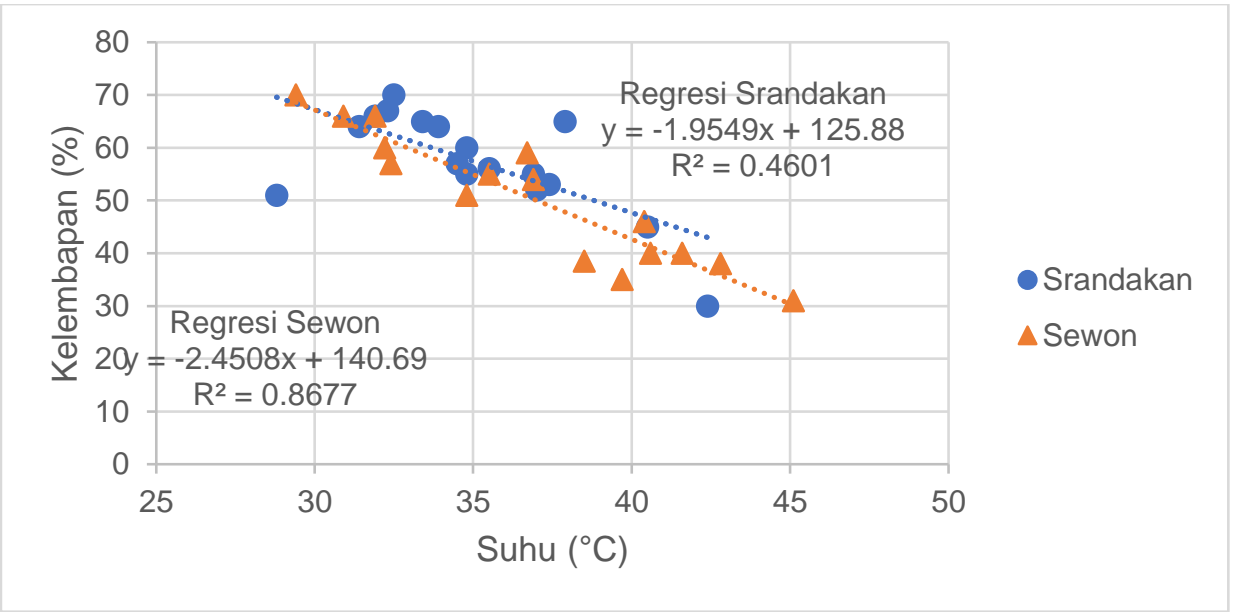

Gambar 1. Regresi kelembapan udara terhadap suhu lingkungan di lokasi Srandakan dan Sewon.

Seiring meningkatnya suhu di bulan Agustus, maka terjadi penurunan kelembapan udara yang lebih tajam pada lahan Sewon terutama ketika suhu diatas $32^{\circ} \mathrm{C}$. Fenomena ini dapat disebabkan oleh kecepatan angin dan naungan pada kedua lokasi. Lahan Srandakan memiliki kecepatan angin yang tinggi membawa uap air sebaliknya lahan Sewon dengan kecepatan angin yang rendah menyebabkan uap air dengan mudah menguap dan kelembapan udara menjadi rendah. Kelembapan udara memilki peran penting dalam status hara tanaman. Kelembapan udara yang tinggi memacu pertumbuhan karna meningkatkan pembukaan stomata sehingga lebih banyak $\mathrm{CO}_{2}$ yang masuk menyebabkan meningkatnya laju fotosintesis. (Roriz et al., 2014).

Tabel 1. Hasil pengujian sifat kimiawi tanah pada lokasi Srandakan dan Sewon

\begin{tabular}{|c|c|c|c|}
\hline \multirow[b]{2}{*}{ Sifat Kimiawi Tanah } & \multicolumn{2}{|c|}{ Lokasi } & \multirow{2}{*}{ Harkat } \\
\hline & Srandakan & Sewon & \\
\hline - & $2.48 \%$ & $2.85 \%$ & - \\
\hline BO & $2.84 \%$ & $2.28 \%$ & Sedang ${ }^{*}$ \\
\hline $\mathrm{pH}$ & 6.15 & 6.35 & Agak Masam ** \\
\hline $\mathrm{N}$ total & $0.0427 \%$ & $0.0370 \%$ & Sangat Rendah* \\
\hline P Tersedia (ppm) & 38.69 & 42.18 & Sedang*** \\
\hline K Tersedia (ppm) & 31.35 & 51.76 & Sedang ${ }^{* *}$ \\
\hline $\mathrm{C} / \mathrm{N}$ & 66.61 & 61.63 & Sangat Tinggi* \\
\hline
\end{tabular}


Tabel 2. Hasil pengujian sifat fisik pada lokasi Srandakan dan Sewon

\begin{tabular}{ccc}
\multicolumn{1}{c}{ Sifat Fisik Tanah } & \multicolumn{2}{c}{ Lokasi } \\
\cline { 2 - 3 } & Srandakan & Sewon \\
\hline Fraksi Penyusun Tanah & & \\
$-\quad$ Pasir (\%) & 53.70 & 52.67 \\
- Debu (\%) & 29.48 & 18.99 \\
$-\quad$ Lempung (\%) & 16.82 & 28.34 \\
- Harkat & Geluh Berpasir & Geluh Lempung Berpasir \\
\hline Konsistensi Tanah & & \\
- Kelekatan & Agak Lekat & Agak Lekat \\
- Plastisitas & Agak Plastis & Agak Plastis \\
- Jenis & Inceptisol & Inceptisol \\
\hline
\end{tabular}

Karakter tanah yang diamati pada Tabel 1. dan Tabel 2. menunjukan tanah pada kedua jenis lokasi tidak menunjukan adanya perbedaan, terutama pada sifat kimiawi. Sifat fisik tanah memiliki perbedaan pada fraksi penyusun tanah. Sewon memiliki tingkat lempung yang lebih tinggi sehingga dikelompokan sebagai tanah geluh lempung berpasir, sedangkan Srandakan memiliki tingkat debu yang lebih tinggi sehingga dikelompokan sebagai tanah geluh berpasir. Konsistensi tidak menunjukan adanya perbedaan pada kedua lingkungan.

Sifat tanah seperti tekstur, kemampuan menyimpan air, dan kesuburan berpengaruh erat dengan ketersediaan $\mathrm{N}$ dan hasi panen. Beberapa studi menunjukan respon nitrogen pada tanaman jagung dipengaruhi secara marginal oleh tektur tanah (Tremblay et al., 2012). Adiaha (2016), dalam penelitiannya menunjukan tanah geluhan dengan kombinasi perlakuan pupuk tertentu memiliki pertumbuhan jagung yang paling signifikan jika dibandingan dengan kontrol. Inceptisol memiliki kadar yang hara yang rendah dan merupakan tanah yang tua. Tanah inceptisol memerlukan asupan pembenah tanah untuk menghasilkan pertanaman yang berkelanjutan (Cuvaca et al., 2015).

Menurut, Chen et al. (2013), solusi dari permasalahan pemupukan N adalah dengan meningkatakan efisiensi penggunaan nitrogen (NUE) pada produksi jagung. Salah satu caranya adalah mengembangkan jagung dengan NUE yang tinggi berdampingan dengan produktifitasnya Pemberian $\mathrm{N}$ pada tingkatan yang optimal memiliki potensi untuk peningkatan efisiensi penggunaan $\mathrm{N}$, keuntungan yang didapat dan dampaknya terhadap lingkungan (Tremblay et al., 2012). Pemberian pupuk mineral (anorganik) dapat meningkatkan pertumbuhan tanaman dan bulir hasil pada tanaman jagung (Adiaha,2016).

Pemupukan pada penelitian dilakukan dengan dosis $600 \mathrm{~kg} / \mathrm{ha}$ pupuk NPK untuk perlakukan pemberian $\mathrm{N}$ dan hanya pupuk organik untuk perlakuan tanpa pemberian $\mathrm{N}$. Pada umumnya tanah pada daerah tropis basah mengalami kekurangan nutrisi $\mathrm{N}, \mathrm{P}$, dan $\mathrm{K}$ 
Perbedaan lingkungan menunjukkan signifikansi pada tinggi tanaman. Srandakan+Pupuk $\mathrm{N}$ dan Sewon+Pupuk $\mathrm{N}$ merupakan lingkungan dengan tanaman tertinggi dengan rentang $210-215 \mathrm{~cm}$. Sewon+Tanpa N memilki nilai tinggi tanaman yang lebih tinggi daripada lingkungan Srandakan+Tanpa $\mathrm{N}$ dengan perbedaan mencapai $23 \mathrm{~cm}$. Srandakan+Pupuk $\mathrm{N}$ dan Sewon+Pupuk $\mathrm{N}$ merupakan lingkungan dengan perlakuan pemberian $\mathrm{N}$ sehingga menunjang pertumbuhan tinggi tanaman. Sewon+Tanpa $\mathrm{N}$ dan Srandakan+Tanpa $\mathrm{N}$ merupakan lingkungan dengan perlakuan tanpa pemberian $\mathrm{N}$, dengan Sewon+Tanpa $\mathrm{N}$ lebih tinggi menunjukkan tinggi tanaman lebih bertumbuh pada kondisi lahan sawah daripada lahan pesisir.

Nisbah tinggi tongkol menunjukkan signifikansi pada jenis kultivar. 'Srikandi' dan Jagung Putih memiliki nisbah tinggi tongkol tertinggi di atas 40\%. 'Bisi 816', 'Lamuru', 'Sukmaraga', 'Bima 20', 'Pioneer 35' memiliki rasio tinggi tongkol di bawah 40\%. 'Srikandi' merupakan kultivar OP dan Jagung Putih merupakan kultivar inbrida. Secara umum kedua kultivar tersebut menunjukkan nilai rasio tertinggi yang menandakan letak tongkol akan proporsional terhadap kenaikan tinggi tanaman. Lingkungan tidak menyebabkan perbedaan yang signifikan pada rasio tinggi tongkol.

Lingkar batang menunjukkan signifikansi pada jenis kultivar. 'Bisi 816', 'Bima 20' merupakan kultvar dengan lingkar batang terbesar. 'Lamuru', 'Pioneer 35', 'Srikandi' merupakan kultivar dengan lingkar batang sedang, disusul dengan 'Sukmaraga' dengan lingkar batang $5 \mathrm{~cm}$. Jagung putih merupakan kultivar dengan lingkar batang terkecil. 'Bisi 816', 'Pioneer 35' dan 'Bima 20' merupakan kultivar hibrida yang menunjukkan lingkar batang yang lebih besar daripada kultivar OP. Kelompok kultivar OP ('Lamuru', 'Sukmaraga', dan 'Srikandi') memiliki lingkar batang sedang menuju tinggi. Jagung putih merupakan kultivar inbrida yang menunjukkan lingkar batang yang paling kecil.

Lingkar batang menunjukkan signifikansi pada perbedaan lingkungan. Lingkar batang terbesar berada di lingkungan Srandakan+Pupuk $\mathrm{N}$ sebesar $5.8 \mathrm{~cm}$. Srandakan+Tanpa $\mathrm{N}$ dan Sewon+Pupuk $\mathrm{N}$ memilki lingkar batang yang tidak berbeda secara signifikan sebesar $5.04 \mathrm{~cm}$. Lingkar batang terendah ditemukan pada Sewon+Tanpa $\mathrm{N}$ sebesar $4.74 \mathrm{~cm}$. Lingkar batang terlihat memiliki kecenderungan besar pada lingkungan pesisir dan adanya perlakuan pemberian $\mathrm{N}$.

Tinggi tanaman merupakan sifat yang pada prinsipnya ditentukan oleh jenis varietas atau genotipe dan waktu penyemaian. Dalam beberapa penelitian penambahan $\mathrm{N}$ tidak memberikan efek yang signifikan terhadap pertumbuhan tanaman, tetapi memiliki efek yang 
Perbedaan lingkungan menunjukkan signifikansi pada karakter panjang tongkol. Srandakan+Pupuk N merupakan lingkungan yang menghasilkan jagung dengan panjang tongkol tertinggi. Srandakan+Tanpa N dan Sewon+Pupuk N merupakan lingkungan dengan panjang tongkol sedang dengan rentang $14-15 \mathrm{~cm}$, dan Sewon+Tanpa N merupakan lingkungan dengan panjang tongkol terependek sebesar $13 \mathrm{~cm}$. Karakter panjang tongkol berkaitan pada lingkungan pesisir dan pemberian $\mathrm{N}$.

Jumlah baris menunjukkan signifikansi pada jenis kultivar. 'Bisi 816', 'Lamuru', 'Pioneer 35', dan 'Srikandi' merupakan kultivar dengan jumlah baris sebesar 14. 'Sukmaraga' dan 'Bima 20' memiliki jumlah baris sebesar 13. dan jagung putih memiliki jumlah baris terkecil sebesar 8 . Perbedaan jumlah baris antar kultivar OP maupun hibrida tidak terlalu signifikan yaitu rentang 13 - 14 baris. Kultivar inbrida menunjukkan karakter jumlah baris terkecil. Sebagian besar lingkungan memiliki rentang jumlah baris sekitar 12 13. Hal tersebut menunjukkan tidak banyak perbedaan yang terjadi dalam keadaan lingkungan dan perlakuan pemberian pupuk.

Bobot 100 benih hanya menunjukkan signifikansi terdapat pada lingkungan. Bobot 100 benih tertinggi terdapat pada lingkungan Sewon+Pupuk $N$ dengan bobot 31,245 gram, kemudian Srandakan+Pupuk N dan Sewon+Tanpa N dengan rentang 27-29 gram. Bobot 100 benih terendah pada Srandakan+Tanpa N yaitu 26 gram. Bobot 100 benih dipengaruhi oleh jenis lahan sawah dan perlakuan pemberian $\mathrm{N}$.

Diameter tongkol memiliki interaksi yang signifikan (Tabel 5.). Kultivar 'Bisi 816' menunjukkan diameter tongkol terbesar pada lahan Srandakan+Pupuk N, dengan diameter sebesar 5.02 cm. Kultivar 'Bisi 816' dan 'Pioneer 35' menunjukkan diameter tongkol terbesar pada lahan Srandakan+Tanpa N dengan rentang diameter sebesar 4.4-4.5 cm. 'Bisi 816' dan 'Pioneer 35' juga menunjukkan hasil yang tinggi pada lahan Sewon+Pupuk N. 
Tabel 4. Diameter tongkol, jumlah bulir per baris dan jumlah bulir per tongkol dari kombinasi 7 kultivar pada 4 lingkungan.

\begin{tabular}{|c|c|c|c|c|c|c|c|c|c|}
\hline \multicolumn{4}{|c|}{ Perlakuan } & \multicolumn{6}{|c|}{ Komponen Hasil } \\
\hline \multicolumn{2}{|c|}{ Lingkungan } & \multicolumn{2}{|r|}{ Kultivar } & \multicolumn{2}{|c|}{$\begin{array}{l}\text { Diameter } \\
\text { Tongkol } \\
\text { (cm) }\end{array}$} & \multicolumn{2}{|c|}{$\begin{array}{c}\text { Jumlah Bulir } \\
\text { per Baris }\end{array}$} & \multicolumn{2}{|c|}{$\begin{array}{l}\text { Jumlah Buli } \\
\text { per Tongkol }\end{array}$} \\
\hline \multirow{14}{*}{ Srandakan } & \multirow{7}{*}{$\begin{array}{l}\text { Pupuk } \\
\text { N }\end{array}$} & \multirow{3}{*}{ Hibrida } & 'Bima 20' & 4.65 & $\mathrm{~cd}$ & 31.50 & d & 442.35 & b \\
\hline & & & 'Bisi 816' & 5.02 & a & 39.48 & a & 532.15 & $a b$ \\
\hline & & & 'Pioneer 35' & 4.80 & b & 40.44 & $\mathrm{a}$ & 587.98 & $\mathrm{a}$ \\
\hline & & \multirow{3}{*}{ OP } & 'Lamuru' & 4.70 & $\mathrm{bc}$ & 31.25 & d & 467.85 & b \\
\hline & & & 'Srikandi' & 4.36 & e & 33.51 & c & 437.98 & b \\
\hline & & & 'Sukmaraga' & 4.50 & d & 36.55 & $b$ & 448.18 & $\mathrm{~b}$ \\
\hline & & Inbrida & Jagung putih & 3.39 & $f$ & 16.23 & $\mathrm{e}$ & 128.58 & $c$ \\
\hline & \multirow{7}{*}{$\underset{\mathrm{N}}{\text { Tanpa }}$} & \multirow{3}{*}{ Hibrida } & 'Bima 20' & 4.23 & b & 26.42 & c & 357.38 & $\mathrm{~b}$ \\
\hline & & & 'Bisi 816' & 4.59 & a & 28.97 & b & 417.03 & $a b$ \\
\hline & & & 'Pioneer 35' & 4.43 & $\mathrm{a}$ & 37.79 & $\mathrm{a}$ & 540.78 & $\mathrm{a}$ \\
\hline & & \multirow{3}{*}{ OP } & 'Lamuru' & 4.17 & b & 29.14 & b & 305.83 & b \\
\hline & & & 'Srikandi' & 4.12 & b & 26.29 & c & 367.13 & b \\
\hline & & & 'Sukmaraga' & 4.22 & b & 29.26 & $\mathrm{~b}$ & 395.55 & $\mathrm{~b}$ \\
\hline & & Inbrida & Jagung putih & 3.29 & C & 17.80 & d & 123.19 & C \\
\hline \multirow{14}{*}{ Sewon } & \multirow{7}{*}{$\begin{array}{l}\text { Pupuk } \\
\text { N }\end{array}$} & \multirow{3}{*}{ Hibrida } & 'Bima 20' & 4.39 & e & 28.13 & d & 344.69 & b \\
\hline & & & 'Bisi 816' & 4.76 & a & 29.31 & $\mathrm{~cd}$ & 386.26 & b \\
\hline & & & 'Pioneer 35' & 4.71 & a & 39.43 & $\mathrm{a}$ & 557.33 & $\mathrm{a}$ \\
\hline & & \multirow{3}{*}{ OP } & 'Lamuru' & 4.51 & C & 28.39 & d & 387.10 & b \\
\hline & & & 'Srikandi' & 4.59 & $b$ & 30.38 & bc & 418.23 & b \\
\hline & & & 'Sukmaraga' & 4.47 & d & 31.28 & $\mathrm{~b}$ & 377.28 & $\mathrm{~b}$ \\
\hline & & Inbrida & Jagung putih & 3.37 & $f$ & 20.86 & e & 177.54 & c \\
\hline & \multirow{7}{*}{$\underset{N}{\text { Tanpa }}$} & \multirow{3}{*}{ Hibrida } & 'Bima 20' & 4.28 & bc & 27.33 & b & 324.41 & b \\
\hline & & & 'Bisi 816' & 4.69 & a & 27.34 & b & 349.53 & b \\
\hline & & & 'Pioneer 35' & 4.26 & c & 30.63 & a & 434.92 & a \\
\hline & & \multirow{3}{*}{ OP } & 'Lamuru' & 4.47 & b & 26.47 & c & 333.08 & b \\
\hline & & & 'Srikandi' & 4.30 & bc & 25.45 & e & 332.15 & b \\
\hline & & & 'Sukmaraga' & 4.04 & d & 26.06 & d & 314.65 & b \\
\hline & & Inbrida & Jagung putih & 3.19 & $\mathrm{e}$ & 15.64 & $f$ & 123.88 & C \\
\hline \multicolumn{4}{|c|}{$\begin{array}{l}\text { Interaksi } \\
\text { CV (\%) }\end{array}$} & \multicolumn{2}{|c|}{$\begin{array}{c}+ \\
7.23 \\
\end{array}$} & \multicolumn{2}{|l|}{$\begin{array}{c}+ \\
1.86 \\
\end{array}$} & \multicolumn{2}{|c|}{$\begin{array}{c}++ \\
12.27 \\
\end{array}$} \\
\hline
\end{tabular}

Keterangan : (+) menunjukkan adanya interaksi; data yang ditampilkan adalah rerata; angka rerata diikuti huruf yang sama menunjukkan tidak adanya beda nyata pada uji Tukey's Honest Significant Difference pada taraf $5 \%$. Huruf hanya berlaku pada masing-masing bagian pada tiap lingkungan. OP merupakan kultivar Open Pollinated.

Dengan besar diameter $\pm 4.7 \mathrm{~cm}$. Kultivar 'Bisi 816' merupakan kultivar dengan diameter tongkol terbesar yaitu $4.69 \mathrm{~cm}$. Jagung putih menunjukkan diameter tongkol terkecil pada seluruh lingkungan dengan diameter tongkol berkisar dari 3.1-3.3 cm. Kultivar 'Bisi 816' menunjukkan diameter tertinggi pada kesuluruhan lingkungan, menunjukkan 'Bisi 816' merupakan kultivar hibrida dengan karakter diameter tongkol yang tinggi. 'Pioneer 35' menunjukkan nilai diameter tongkol yang cukup besar di bawah 'Bisi 816'. Kultivar-kultivar 
OP ('Sukmaraga', 'Lamuru', dan 'Srikandi') menunjukkan performa diameter tongkol yang sedang pada seluruh lingkungan.

Jumlah bulir per baris menunjukkan adanya GEl yang signifikan (Tabel 5.). Kultivar 'Pioneer 35' menunjukkan keunggulan jumlah bulir per baris pada seluruh lingkungan dengan kisaran nilai pada lahan yang diberi pupuk $N$ sebesar $39-40$ bulir per baris, pada lahan Srandakan+Tanpa N sebesar 37 bulir per baris, dan pada lahan Sewon+Tanpa N sebesar 30 bulir per baris. Kultivar lainya yang menunjukkan bulir per baris tinggi adalah 'Sukmaraga' pada hampir semua lingkungan kecuali pada lahan Sewon+Tanpa N.

'Bisi 816' menunjukkan jumlah bulir per baris yang tinggi pada hampir seluruh lingkungan. Jagung putih menunjukkan jumlah bulir per baris terendah pada keseluruhan lingkungan dengan rentang jumlah bulir per baris sebanyak 15-20 bulir. Jumlah bulir per baris tidak banyak terlihat perbedaanya pada lingkungan, tetapi ada interaksi khusus yang serupa antara kultivar hibrida dengan lahan yang diberi perlakuan penambahan N. Inbrida jagung putih menunjukkan jumlah bulir per baris paling rendah.

Jumlah bulir per tongkol menunjukkan adanya GEI yang signifikan (Tabel 5.). Jumlah bulir total tertinggi didominasi oleh 'Pioneer 35' pada seluruh lingkungan dengan rentang 430580 bulir per tongkol. Kultivar inbrida jagung putih menunjukkan sifat jumlah bulir yang rendah pada seluruh lingkungan dengan rentang 120-170 bulir per tongkol. Kultivar-kultivar selain kedua kultivar di atas tidak menunjukkan adanya perbedaan yang cukup tinggi pada seluruh lingkungan. Karakter jumlah bulir terlihat dipengaruhi oleh lingkungan Srandakan+Pupuk N. Interaksi lingkungan (kecuali lingkungan Srandakan+Pupuk N) yang terjadi dengan kultivar OP dan hibrida tidak menunjukkan perbedaan yang cukup signifikan. 
Tabel 5. Bobot panen total, bobot piilan 10 tongkol, dan rendemen, dari kombinasi 7 kultivar pada 4 lingkungan

\begin{tabular}{|c|c|c|c|c|c|c|c|c|c|}
\hline \multicolumn{4}{|c|}{ Perlakuan } & \multicolumn{6}{|c|}{ Komponen Hasil } \\
\hline \multicolumn{2}{|c|}{ Lingkungan } & \multicolumn{2}{|r|}{ Kultivar } & \multicolumn{2}{|c|}{$\begin{array}{l}\text { Berat Panen } \\
\text { Total (gram) }\end{array}$} & \multicolumn{2}{|c|}{$\begin{array}{c}\text { Berat } \\
\text { Pipilan } 10 \\
\text { Tongkol } \\
\text { (gram) }\end{array}$} & \multicolumn{2}{|c|}{ Rendemen } \\
\hline \multirow{14}{*}{ Srandakan } & \multirow{7}{*}{$\begin{array}{l}\text { Pupuk } \\
\text { N }\end{array}$} & \multirow{3}{*}{ Hibrida } & 'Bima 20' & 3475 & $a b c$ & 1263 & bc & $79.81 \%$ & a \\
\hline & & & 'Bisi 816' & 3935 & $a b$ & 1633 & $a b$ & $80.93 \%$ & a \\
\hline & & & 'Pioneer 35' & 4578 & $\mathrm{a}$ & 1680 & $\mathrm{a}$ & $84.63 \%$ & a \\
\hline & & \multirow{3}{*}{ OP } & 'Lamuru' & 2985 & bc & 1375 & $a b c$ & $82.72 \%$ & a \\
\hline & & & 'Srikandi' & 2450 & $c$ & 1158 & c & $79.63 \%$ & a \\
\hline & & & 'Sukmaraga' & 3370 & bc & 1268 & bc & $75.07 \%$ & $\mathrm{a}$ \\
\hline & & Inbrida & Jagung putih & 550 & d & 363 & d & $76.36 \%$ & $\mathrm{a}$ \\
\hline & \multirow{7}{*}{$\underset{N}{\text { Tanpa }}$} & \multirow{3}{*}{ Hibrida } & 'Bima 20' & 1700 & $\mathrm{~b}$ & 898 & $a b$ & $78.77 \%$ & $a b$ \\
\hline & & & 'Bisi 816' & 2380 & $a b$ & 1045 & $a b$ & $78.29 \%$ & $a b$ \\
\hline & & & 'Pioneer 35' & 2953 & $\mathrm{a}$ & 1320 & $\mathrm{a}$ & $80.56 \%$ & $\mathrm{a}$ \\
\hline & & \multirow{3}{*}{ OP } & 'Lamuru' & 1548 & $\mathrm{~b}$ & 735 & $\mathrm{bc}$ & $72.81 \%$ & $a b$ \\
\hline & & & 'Srikandi' & 1843 & b & 915 & $a b$ & $87.79 \%$ & a \\
\hline & & & 'Sukmaraga' & 1943 & $a b$ & 933 & $a b$ & $80.11 \%$ & $\mathrm{a}$ \\
\hline & & Inbrida & Jagung putih & 340 & C & 213 & C & $64.54 \%$ & $\mathrm{~b}$ \\
\hline \multirow{14}{*}{ Sewon } & \multirow{7}{*}{$\begin{array}{l}\text { Pupuk } \\
\text { N }\end{array}$} & \multirow{3}{*}{ Hibrida } & 'Bima 20' & 1453 & c & 940 & b & $78.67 \%$ & a \\
\hline & & & 'Bisi 816' & 3368 & a & 1158 & b & $75.60 \%$ & a \\
\hline & & & 'Pioneer 35' & 3590 & $\mathrm{a}$ & 1730 & a & $82.59 \%$ & $\mathrm{a}$ \\
\hline & & \multirow{3}{*}{ OP } & 'Lamuru' & 2333 & $\mathrm{bc}$ & 1120 & $\mathrm{~b}$ & $75.86 \%$ & $a$ \\
\hline & & & 'Srikandi' & 2873 & $a b$ & 1268 & b & $78.57 \%$ & a \\
\hline & & & 'Sukmaraga' & 1950 & bc & 1040 & b & $79.15 \%$ & $\mathrm{a}$ \\
\hline & & Inbrida & Jagung putih & 483 & $d$ & 365 & C & $78.33 \%$ & $a$ \\
\hline & \multirow{7}{*}{$\underset{N}{\text { Tanpa }}$} & \multirow{3}{*}{ Hibrida } & 'Bima 20' & 1693 & $\mathrm{a}$ & 953 & $a$ & $78.75 \%$ & $a$ \\
\hline & & & 'Bisi 816' & 2325 & a & 1098 & a & $77.17 \%$ & a \\
\hline & & & 'Pioneer 35' & 2108 & a & 1005 & a & $77.80 \%$ & a \\
\hline & & \multirow{3}{*}{ OP } & 'Lamuru' & 2173 & $a$ & 1003 & $a$ & $76.82 \%$ & $a$ \\
\hline & & & 'Srikandi' & 1588 & $a b$ & 928 & a & $77.20 \%$ & a \\
\hline & & & 'Sukmaraga' & 1453 & $a b$ & 813 & a & $77.67 \%$ & a \\
\hline & & Inbrida & Jagung putih & 740 & b & 333 & b & $76.89 \%$ & $\mathrm{a}$ \\
\hline \multicolumn{4}{|l|}{$\begin{array}{l}\text { Interaksi } \\
\text { CV (\%) }\end{array}$} & \multicolumn{2}{|c|}{$\begin{array}{c}+ \\
19.82\end{array}$} & \multicolumn{2}{|c|}{18.24} & \multicolumn{2}{|l|}{$\begin{array}{c}+ \\
6.25\end{array}$} \\
\hline
\end{tabular}

Keterangan : (+) menunjukkan adanya interaksi; data yang ditampilkan adalah rerata; angka rerata diikuti huruf yang sama menunjukkan tidak adanya beda nyata pada uji Tukey's Honest Significant Difference pada taraf $5 \%$. Huruf hanya berlaku pada masing-masing bagian pada tiap lingkungan. OP merupakan kultivar Open Pollinated.

Bobot panenan total menunjukkan adanya signifikansi pada GEI (Tabel 6.). Lahan Srandakan+Pupuk N didominasi oleh kultvar-kultivar hibrida ('Bisi 816', 'Bima 20', dan 'Pioneer 35' sebagai jagung dengan bobot panenan total tertinggi yaitu berkisar dari 3,4 $4,5 \mathrm{~kg}$. Lahan Srandakan+Tanpa $\mathrm{N}$ memiliki bobot panenan total tertinggi pada kultivar 'Pioneer 35' sebesar 2,9 kg. Kultivar OP dan hibrida menunjukkan hasil yang tidak berbeda jauh pada lahan Srandakan+Tanpa $\mathrm{N}$ dengan kisaran 1,5-2,3 kg. 
Bobot panenan total pada lahan Sewon+Pupuk $\mathrm{N}$ didominasi oleh kultivar hibrida 'Bisi 816' dan 'Pioneer 35' dengan rentang sebesar 3,3 - 3,5 kg. Kultivar OP menunjukkan berat yang sedang, dan kultivar 'Bima 20' menunjukkan bobot yang cukup rendah dengan berat $1,4 \mathrm{~kg}$. Lahan Sewon+Tanpa $\mathrm{N}$ menunjukkan berat panenan yang tidak berbeda jauh pada kultivar hibrida dan kultivar OP, dengan rentang 1,4-2,3 kg, dengan 'Bisi 816' sebagai kultivar dengan bobot hasil panenan terbesar. Jagung putih memilki bobot panenan total terendah dengan rentang 300 - 700 gram. Karakter bobot panenan total terlihat dipengaruhi oleh lingkungan dengan penambahan N. Kultivar inbrida Jagung putih menunjukkan bobot panenan total yang rendah.

Bobot pipilan 10 tongkol menunjukkan adanya signifikansi pada GEI (Tabel 6.). Bobot pipilan 10 tongkol pada lahan Srandakan+Pupuk N menunjukkan 'Bisi 816' dan 'Pioneer 35' memiliki berat tertinggi sebesar \pm 1,6 kg. Kultivar-kultivar OP dan 'Bima 20' menunjukkan bobot pipilan 10 tongkol sedang. Lahan Srandakan+Tanpa N menunjukkan hasil yang tida terlalu berbeda pada seluruh kultivar hibrida maupun kultivar OP, dengan rentang 890 - 1300 gram. Pengecualian terjadi pada kultivar 'Srikandi' yang memiliki bobot pipilan yang cukup rendah sebesar 735 gram. 'Pioneer 35 ' menunjukkan nilai tertinggi dengan bobot pipilan 10 tongkol sebesar $1,3 \mathrm{~kg}$.

Lahan Sewon+Pupuk N menunjukkan bobot pipilan 10 tongkol tertinggi pada kultivar 'Pioneer 35' sebesar 1,7 kg. Seluruh kultivar OP dan hibrida memiliki kirasan bobot pipilan sedang yaitu 900 - 1200 gram, kecuali kultivar. Lahan Sewon+Tanpa N menunjukkan bobot pipilan 10 tongkol yang serupa pada seluruh kultivar OP dan hibrida dengan kisaran 800 1000 gram. Jagung putih memilki bobot 10 tongkol terendah pada seluruh lingkungan dengan rentang 200 - 350 gram. Bobot panenan total berkaitan dengan pemberian $\mathrm{N}$ pada lahan terutama pada kultivar hibrida. Interaksi ditemukan pada 'Sukmaraga' dan 'Lamuru' yang ditanam pada lahan tanpa pemberian N menyebabkan menurunnya bobot 10 tongkol.

Rendemen menunjukkan adanya signifikansi pada GEI. Lahan Srandakan+Pupuk N tidak menunjukkan adanya perbedaan yang nyata antar kultivar dengan rentang rendemen sebesar 75 - 84\%. Lahan Srandakan+Tanpa N juga menunjukkan sedikit perbedaan antar kultivar. Kultivar 'Srikandi' menunjukkan hasil yang cukup besar dengan rendemen 87\% pada lahan tersebut. Lahan Sewon+Pupuk $\mathrm{N}$ menunjukkan tidak adanya perbedaan rendemen yang nyata antar kultivar dengan rentang $75-82 \%$.

Lahan Sewon+Tanpa N menunjukkan hasil yang serupa tetapi dengan rentang hasil rendemen yang lebhih kecil yaitu 76 - 78\% Rendemen terlihat dipengaruhi oleh perlakuan 
pemberian pupuk dan menunjukkan adanya interaksi yang bersifat menurunkan nilai rendemen dengan lahan pesisir tanpa adanya pemberian N. Kultivar inbrida jagung putih memiliki rendemen yang beragam sesuai dengan jenis interaksi dengan lingkunganya.

Begum et al. (2016) dalam penelitiannya menunjukkan adanya pengaruh langsung positif yang signifikan dari tinggi tanaman, panjang tongkol, jumlah bulir per baris. Selain itu, Alvi et al., (2003) menemukan adanya korelasi siginifikan terhadap hasil ditemukan pada jumlah baris per tongkol, jumlah bulir per baris, dan bobot 1000 benih yang besifat positif. Jumlah bulir per tongkol juga merupakan faktor utama yang mempengaruhi hasil. Dalam pengembangan hibrida, sifat seperti diameter tongkol, jumlah bulit per tongkol, dan tinggi tanaman merupakan sifat yang penting. Korelasi tertinggi diurutkan dari jumlah bulir per baris, kemudian tinggi tanaman dan panjang tongkol.

Potensi hasil panen menunjukan adanya signifikansi pada GEI (Tabel 7.). 'Pioneer 35' pada lingkungan Sewon+Pupuk N menunjukan potensi hasil terbesar yaitu 9.5 ton/ha. Sebagian besar kultivar 'Pioneer 35' dan lingkungan Srandakan+Pupuk $\mathrm{N}$ menunjukan potensi hasil diatas 6 ton/ha. Kultivar - kultivar pada lingkungan Sewon+Tanpa N dan Sewon+Pupuk N menunjukan potensi hasil yang cukup besar pada rentang $5-7$ ton/ha. Lahan Srandakan+Pupuk N menunjukan kultivar 'Bisi 816' dan 'Lamuru' menunjukan potensi hasil yang tinggi yaitu 8,66 ton/ha dan 7,8 ton/ha. 'Bima 20 ' memiliki potensi hasil sekitar 6,3-6,7 ton/ha pada lingkungan Srandakan+Pupuk N, Srandakan+Tanpa N dan Sewon+Tanpa N.

'Sukmaraga' dan 'Lamuru' pada Srandakan+Tanpa N menunjukan potensi hasil panen yang cukup rendah yaitu 4,7 ton/ha dan 4 ton/ha. Jagung Putih menunjukan hasil panenan dengan rentang 1,5-3 ton/ha. Potensi hasil panen pada kultivar hibrida terlihat lebih tinggi terutama pada lingkungan dengan perlakuan pemberian N. Kultivar OP menunjukan hasil yang cukup stabil pada lingkungan dengan tanpa pemberian $\mathrm{N}$. Lingkungan pesisir dengan perlakuan tanpa pemberian $\mathrm{N}$ menunjukan potensi hasil terendah. Jagung Putih menunjukan performa kultivar inbrida pada lingkungan manapun menunjukan potensi hasil terendah. 
Tabel 6. Potensi hasil dari kombinasi 7 kultivar pada 4 lingkungan

\begin{tabular}{|c|c|c|c|c|c|c|c|c|c|}
\hline \multicolumn{10}{|c|}{ Potensi Hasil (ton/ha) } \\
\hline & \multirow{3}{*}{ Kultivar } & \multicolumn{8}{|c|}{ Lingkungan } \\
\hline & & \multicolumn{4}{|c|}{ Srandakan } & \multicolumn{4}{|c|}{ Sewon } \\
\hline & & \multicolumn{2}{|c|}{ Pupuk N } & \multicolumn{2}{|c|}{ Tanpa N } & \multicolumn{2}{|c|}{ Pupuk N } & \multicolumn{2}{|c|}{ Tanpa N } \\
\hline & 'Bima 20' & 6.47 & $a b$ & 5.33 & $a b$ & 6.75 & $a b$ & 6.39 & $\mathrm{a}$ \\
\hline \multirow[t]{3}{*}{ Hibrida } & ‘Bisi 816’ & 8.67 & a & 5.74 & $a b$ & 6.98 & $a b$ & 6.23 & a \\
\hline & 'Pioneer 35' & 8.53 & a & 7.52 & $\mathrm{a}$ & 9.53 & a & 5.57 & a \\
\hline & 'Lamuru' & 7.83 & $a b$ & 4.03 & $\mathrm{bc}$ & 6.13 & bc & 6.80 & a \\
\hline \multirow[t]{2}{*}{ OP } & 'Srikandi' & 6.16 & $b$ & 5.62 & $a b$ & 6.80 & $a b$ & 5.23 & a \\
\hline & 'Sukmaraga' & 6.87 & $a b$ & 4.73 & $a b$ & 5.65 & $\mathrm{bc}$ & 5.23 & a \\
\hline Inbrida & 'Jagung putih & 2.20 & C & 1.62 & C & 3.27 & C & 2.33 & $b$ \\
\hline & $\begin{array}{l}\text { Interaksi } \\
\text { CV (\%) }\end{array}$ & & & & & & & & \\
\hline
\end{tabular}

Keterangan : (+) menunjukan adanya interaksi; data yang ditampilkan adalah rerata; angka rerata diikuti huruf yang sama menunjukan tidak adanya beda nyata pada uji Tukey's Honest Significant Difference pada taraf $5 \%$. Huruf hanya berlaku pada masing-masing bagian pada tiap lingkungan. OP merupakan kultivar Open Pollinated.

Hasil panen merupakan karakter kompleks yang dihasilkan dari berbagai hubungan internal komponen-komponen pertumbuhan, yang juga sangat dipengaruhi oleh keadaan lingkungan (Begum et al., 2016). Potensi hasil panen dipengaruhi oleh jenis genotipe dengan kultivar hibrida memiliki hasil panen yang lebih tinggi, dan lingkungan dengan penambahan $\mathrm{N}$ menunjukkan hasil panen yang lebih baik. Pengaruh lingkungan akan menyebabkan perbedaan performa masing-masing genotipe.

Kultivar OP dapat berkompetisi pada agroekosistem dengan produktivitas rendah dan ketika harga jagung pasar menurun. Secara ekonomis proses pemuliaan untuk kultivar OP dan hibrida tidak memilki perbedaan yang nyata (Kutna, 2011). Kultivar hibrida yang sangat baik dapat memiliki hasil yang lebih tinggi sebanyak $70 \%$ dari kultivar OP. Rata rata hasil panen kultivar hibrida menunjukkan 18\% lebih besar daripada kultivar OP. (McPhearson, 2011).

\section{KESIMPULAN}

Hasil menunjukkan kultivar hibrida memiliki performa yang baik pada lingkungan dengan pemberian N. Kultivar OP memiliki performa sedang pada seluruh lingkungan dan kultivar inbrida memiliki performa rendah di seluruh lingkungan. 


\section{DAFTAR PUSTAKA}

Adiaha, M. S. 2016. Influence of different soil types and mineral fertilizer on maize (Zea mays L.) growth for effective production, soil fertility improvement and food security. World Scientific News. 55: 137-167

Alvi, M.B., M. Rafique, and M.S. Tariq. 2003. Character association and path coefficient analysis of grain yield and yield components maize (Zea mays L.). Pakistan Journal of Biological Sciences. 6(2): 136-138.

Begum, S., A. Ahmed, S. H. Omy, M. M. Rohman And M. Amiruzzaman. 2016. Genetic variability, character association and path analysis in maize (Zea mays L.). Bangladesh. J Agril Res. 41(1): 173-182.

Belfield, S. and C. Brown.2008. Field crop manual: Maize a guide to upldan production in Cambodia. New South Wales Department of Primary Industries. Cambodia.

Bose, L.K., N.N. Jambhulkar, K. Pande, and O.N. Singh. 2014. Use of AMMI and other stability statistics in simultaneous selection of rice genotipes for yield and stability under direct seeded condition. Chilean Journal of Agricultural Research. 74(1).

Brewbaker, J. L. 2003. Corn production in the tropics the hawaii experience. College of Tropical Agriculture and Human Resources. Hawaii.

Cambouris, A.N., N. Ziadi, I. Perron, K. D. Alotaibi, M. St. Luce, and N. Tremblay. 2016. Corn yield components response to nitrogen fertilizer as a function of soil tekstur. Can. J Soil Sci. 96: 114

Chen, FanJun, F. ZenGuo, G. Qiang, Y. YouLiang, J. LiangLiang, Y. LiXing, M. GuoHua and Z. Fusuo. 2013. Evaluation of the yield and nitrogen use efficiency of the dominant maize hybrids grown in North and Northeast China. Sci China Life Sci. 56: 552-560.

Cuvaca, I. B., D. M. Lambert, F. R. Walker, M. Marake and N. S. Eash. 2015. Economically optimal $\mathrm{N}$ fertilizer rates for maize produced on vertisol and inceptisol soils under notill management: A case study in Maphutseng, Lesotho. International Journal of Plant and Soil Science. 8(2): 1-12.

Ghalejoughi, E.S., S. Lack and M.A. Fazel. 2013 Analysis of correlation and stepwise regression between grain yield and related traits of corn hybrids. Intl J Agri Crop Sci. 6(2): 100-102.

Herrera, E. 2000. College of agriculture and home economics. New Mexico State University. Soil Analysis-Guide A-112.

Kandus, M., D. Almorza, R.B. Ronceros, J.C. Salerno. 2010. Statistical models for evaluating the genotipe-environment interaction in maize (Zea mays L.). YTON ISSN 0031 9457. 79: 39-46

Landon, J.R. 1984. Booker Tropical Soil Manual. Booker Agric. Intern. Ltd. United Kingdom.

Lauer, J.L. 2002. Methods for calculating corn yield. Agronomy Advice. University of Wisconsin. 
Mc Pherson, J. 2011. Hybrid or open pollinated variety seed-weigh up the options. Pula Imvula. August 2011

Rao, I. M., J. W. Miles, S. E. Beebe and W. J. Horst. 2016. Root adaptations to soils with low fertility and aluminium toxicity. Annals of Botany. 118: 593-605

Roriz, M., S. M. P. Carvalho and M. W. Vasconcelos 2014. High relative air humidity influences mineral accumulation and growth in iron deficient soybean plants. Frontiers in Plant Science. (5): 726

Syafruddin, M. R., R. Y. Arvan, and M. Akil. 2009. Requirements for N, P, And K fertilizers on inceptisol haplustepts soil. Indonesian Journal of Agriculture. 2(1): 77-84.

Tremblay, N., Y. M. Bouroubi, C. Bélec, R. W. Mullen, N. R. Kitchen, W. E. Thomason, S. Ebelhar, D. B. Mengel, W. R. Raun, D. D. Francis, E. D. Vories, and I. OrtizMonasterio. 2012. Corn response to nitrogen is influenced by soil tekstur and weather. Agronomy Journal. 104(6).

Zarei, B., D. Kahrizi, A. P. Aboughadareh and F. Sadeghi. 2012. Correlation and path coefficient analysis for determining interrelationships among grain yield and related characters in corn hybrids (Zea mays L.). Intl J Agri Crop Sci. 4(20): 1519-1522.

Zsubori, Z., Z. Gyenes-Hegyi, O. Illés, I. Pók, F. Rácz, C. Szőke. 2008. Inheritance of plant and ear height in maize (Zea mays L.). Agricultural Research Institute of the Hungarian Academy of Sciences, Martonvásár. 